\title{
Chromosomal analysis of Barrett's cells: demonstration of instability and detection of the metaplastic lineage involved
}

\author{
Paula Chaves, Mateus Crespo, Catarina Ribeiro, Cátia Laranjeira, A Dias Pereira, \\ Alexandra Suspiro, Paula Cardoso, C Nobre Leitão and Jorge Soares
}

Grupo de Estudo do Esófago de Barrett, Instituto Português de Oncologia de Lisboa de Francisco Gentil, EPE, Lisboa, Portugal

\begin{abstract}
Barrett's esophagus is lined by columnar and goblets cells with gastric and intestinal characteristics. Despite the association between goblet elements and malignancy, it was not demonstrated that other columnar cells lineages are not related to neoplasia. Chromosomal abnormalities were described in metaplasia adjacent to Barrett's neoplasia, but it is unknown which metaplastic lineages are involved. This work assessed the frequency and the type of chromosomal abnormalities in Barrett's esophagus without neoplasia and performed the identification of the metaplastic cells carrying chromosomal gains. Barrett's esophagus biopsies were collected and processed for short-term cell culture and cytogenetic analysis. Combined immunofluorescence/ fluorescence in situ hybridization was performed in cases exhibiting chromosomal gains by using antisera against intestinal (MUC2) and gastric (MUC5AC and MUC6) apomucins and chromosome pericentromeric alpha satellite DNA probes for the chromosomes involved. Each case was scored for the number of spots $(0,1,2,>2)$ in 200 nonoverlapping nuclei. Columnar and goblet cells were separately assessed. Short-term cell cultures were achieved in $40 / 60$ cases $(67 \%)$. There were clonal abnormalities in $27 / 40$ cases $(68 \%)$ and tetraploid $(4 n)$ clones in $10 / 40(25 \%)$. Structural alterations were detected in $14 / 40(35 \%)$ with recurrent breakpoints at 1q21, 15q15 and 15q22. Numerical changes (trisomies 7 and 18 and loss of $Y$ ) occurred in $16 / 40(40 \%)$. Gains of chromosomes 7 and 18 were more frequent in columnar than in goblet cells $(9.8 \%$ vs $0.7 \%(P<0.05))$ and $(7.9$ vs $1.9 \%(P<0.05))$ respectively. These alterations were detected in cells exhibiting gastric as well as intestinal features and were more frequent in cells without apomucin production. Conclusions: (1) chromosomal instability is a common finding in Barrett's esophagus without neoplasia. (2) The two metaplastic populations are committed, chromosomal gains being more frequent in columnar nongoblet than in goblet cells. (3) The two metaplastic phenotypes, gastric and intestinal, are equally involved.
\end{abstract}

Modern Pathology (2007) 20, 788-796; doi:10.1038/modpathol.3800787; published online 25 May 2007

Keywords: Barrett's esophagus; cellular phenotype; chromosomal abnormality; metaplasia

Barrett's esophagus is a premalignant condition in which the normal stratified squamous epithelium is replaced by a metaplastic columnar lining with intestinal differentiation. ${ }^{1,2}$ It develops in $10-14 \%$ of patients with long-standing gastroesophageal reflux disease and it is the sole known precursor of esophageal adenocarcinoma, ${ }^{1,2}$ the tumor whose incidence increased over the last decades at a rate exceeding that of any other cancer type..$^{3-5}$

During the process of metaplasia, a heterogeneous admixture of cellular elements with distinct pheno-

Correspondence: Dr P Chaves, MD, PhD, Serviço de Anatomia Patológica, Instituto Português de Oncologia Francisco Gentil, Rua Prof. Lima Basto, Lisboa 1099-023, Portugal.

E-mail: pchaves@ipolisboa.min-saude.pt

Received 5 December 2006; revised 11 March 2007; accepted 15 March 2007; published online 25 May 2007 types replaces the normal squamous esophageal epithelium. ${ }^{1,2}$ This metaplastic lining is a complex structure including intermingled gastric and intestinal-type epithelia. ${ }^{6-9}$ The latter, is identified by the presence of goblet-shaped cells, the metaplastic element regarded as the hallmark of Barrett's esophagus due to its association with cancer risk. ${ }^{9,10}$ Nevertheless, the prevalent cellular elements of Barrett's esophagus are the columnar nongoblet cells, which exhibit gastric and intestinal characteristics as goblet cells do. ${ }^{11}$

Gastric and intestinal mucosas are protected by a mucus layer of high molecular weight glycoproteins synthesized by normal epithelial cells in a cell- and tissue-specific pattern. ${ }^{12,13}$ MUC5AC and MUC6 are the protein cores of gastric mucus, foveolar and mucopeptic, respectively. MUC2 is the protein 
constituent of the intestinal mucus. This cell- and tissue-specific organization makes these apomucins reliable markers of gastric and intestinal phenotypes.

It is widely accepted that the development of Barrett's adenocarcinoma follows a stepwise mechanism from metaplasia to dysplasia and carcinoma. ${ }^{10}$ This pathway to malignancy is the morphologic counterpart of a progressive accumulation of genetic events (gross chromosomal and/or subtle DNA sequence abnormalities) that lead to genomic instability. ${ }^{14-17}$ Aneuploidy and increased G2/tetraploid fraction, signs of gross DNA chromosomal abnormalities, have been related to Barrett's tumorigenesis. ${ }^{16}$

Conventional cytogenetics is a useful tool to characterize chromosomal abnormalities and a previous study demonstrated the presence of chromosomal defects in Barrett's esophagus. ${ }^{17}$ However, there are very few reports using this technique ${ }^{14,17}$ and, to our knowledge there are no studies correlating the distinct columnar population of Barrett's esophagus without evidence of neoplastic changes with the presence of genetic abnormalities.

The aims of this study were:

1. To assess the frequency and to characterize chromosomal abnormalities in Barrett's esophagus without dysplasia or cancer.

2. To identify the metaplastic cellular lineage carrying these changes.

\section{Materials and methods}

This study was performed in two distinct phases.

In Phase I, epithelial cells from samples of Barrett's esophagus without dysplasia or carcinoma were collected, processed for short-term cell culture and analyzed by cytogenetic analysis after assessment of its phenotype. In Phase II, we used a combined immunofluorescence/fluorescence in situ hybridization (IF-FISH) technique performed on formalin-fixed, paraffin-embedded tissue sections from biopsies obtained during the same endoscopy to identify cells carrying recurrent numerical chromosomal abnormalities and to characterize their morphology and immunophenotype.

\section{Phase I}

Biopsy samples collection

Endoscopic biopsies were obtained from patients enrolled in the Barrett's esophagus Surveillance Program of the Instituto Português de Oncologia de Lisboa, after informed consent. The diagnosis of Barrett's esophagus was based on the histological demonstration of intestinal metaplasia, recognized by the presence of goblet cells, in biopsies taken from red velvet mucosal segments of the distal esophagus. ${ }^{18}$ Only patients with long segments $(\geq 3 \mathrm{~cm})$ of Barrett's esophagus with biopsies negative for dysplasia or carcinoma were included. Presently, all the patients have at least 5 years of regular endoscopic follow-up after inclusion in this study and none developed dysplasia or cancer. Biopsies were collected according to Levine et $a l^{19}$ protocol and samples of 2-3 extra biopsies were obtained for cytogenetic analysis. To prevent contamination, biopsies for cytogenetics were collected during endoscope insertion before gastric and duodenal observation. The material for tissue culture was placed in phosphate-buffered saline (PBS) medium containing penicillin, streptomycin and amphotericin B, and immediately processed. Biopsies for diagnostic purposes were routinely processed and subsequently used in Phase II studies.

\section{Tissue culture}

To establish short-term cell cultures, we used a modified Khan et $a l^{20}$ technique. Briefly, the tissue was mechanically desegregated with scalpels and enzimatically digested using collagenase II $(400 \mathrm{U} /$ $\mathrm{ml}$ ) in Hank's Balanced Salt Solution for $16 \mathrm{~h}$ at $37^{\circ} \mathrm{C}$, until small cell clumps were obtained. The clumps were suspended and washed in RPMI medium and plated out in T25 Primaria flasks (Falcon) and T25 vitrogen-coated flasks (Nunc). The culture medium used for initiation has been used previously for culturing breast epithelial cells. ${ }^{21}$ Cell cultures were then incubated at $37^{\circ} \mathrm{C}$ in a humidified incubator containing $5 \%$ carbon dioxide and left undisturbed for 5 days. Cultures were examined daily on inverted microscopy. The culture medium was replaced twice a week after initiation of cell growth. Upon reaching confluence, cells were trypsinized (Trypsin-EDTA; Gibco-BRL) and plated onto Lab-Tek ${ }^{\mathbb{R}}$ cover glass chamber slides used to perform cytogenetic analysis.

\section{Phenotypic evaluation of the cells obtained by short-term culture}

After the initial subculture, an aliquot of cells was grown on coverslips and fixed in 1\% formaldehyde PBS $1 \times$ for $10 \mathrm{~min}$. The epithelial phenotype of in vitro growing cells was immunohistochemically assessed by using monoclonal antibodies anticytokeratin (CAM 5.2 (Becton Dickinson 349205) and AE1/AE3 (Zymed 18-0132)). For the identification of gastric characteristics, foveolar and mucopeptic, two monoclonal antibodies against the apomucins MUC5AC and MUC6, CLH2 and CLH5 (courtesy of Leonor David, MD, PhD), respectively, were used. Intestinal differentiation was identified by using a monoclonal antibody for the apomucin MUC2 (NCL-MUC-2; Novocastra) normally present at the goblet intestinal cells.

\section{Cytogenetic analysis}

After 15-20 days of in vitro growth, metaphase cells were arrested by exposure to colcemid ${ }^{\mathbb{R}}$ (Gibco) for 6-16 h. The mitotic cells were swelled with $\mathrm{NaCl}$ 
$0.021 \%$ at room temperature for $35-45 \mathrm{~min}$ and fixed progressively with methanol:acetic acid (3:1). The chromosomes were G-banded according to standard cytogenetic methods, and chromosome abnormalities were considered as clonal according to the recommendations of the ISCN. $^{22}$ Briefly, clonality was defined by the presence of any of the following criteria: (1) two cells with the same structural abnormality or nonrandom gain of a given chromosome; (2) three cells with loss of a given chromosome.

\section{Phase II}

Combined IF-FISH study

Endoscopic biopsy samples from the patients with recurrent numerical chromosome abnormalities were used. Formalin-fixed and paraffin-embedded sections with $4 \mu \mathrm{m}$ were processed by using a combined IF-FISH protocol developed for the simultaneous detection of the cellular immunophenotype and the numerical alterations detected previously. The phenotypic characterization of the metaplastic elements was performed with the same panel of antibodies used in Phase I for the identification of gastric and intestinal characteristics in short-term cell culture cells. The slides were incubated for MUC5AC and MUC6 for $24 \mathrm{~h}$ at $4^{\circ} \mathrm{C}$ and for MUC2 for $30 \mathrm{~min}$ at room temperature after: (1) antigen retrieval in citrate buffer $(\mathrm{pH}$ 6.0) using microwave oven for $20 \mathrm{~min}$ at $750 \mathrm{~W}$; (2) pretreatment with $2 \times \mathrm{SSC}$ for $30 \mathrm{~min}$ at $45^{\circ} \mathrm{C}$; (3) proteolytic digestion with pepsin at $4 \mathrm{mg} / \mathrm{ml}$ in $\mathrm{HCl} 0.2 \mathrm{~N}(\mathrm{pH}$ 2.0) for $2 \mathrm{~min}$. The reaction was developed with avidin-Cy3 (Sigma, St Louis, MO, USA). Subsequently, FISH was performed on the same slides. According to the results of previous cytogenetic analysis, we used biotinylated probes specific for the pericentromeric regions of chromosome 7 (Zymed, San Francisco, CA, USA) and chromosome 18 (Q-BIOgene, llkirch, France). Probes were detected by anti-biotin FICT (Ventana, Tucson, AZ, USA). The nuclei were counterstained with DAPI (Vectashield Vector, Burlingame, CA, USA). IF-FISH analysis was performed with an epifluorescent microscope (Olympus BX40) equipped with a triple band beam splitter and emission filters Dapi/Green/ Orange (Olympus BX51). Each case was scored for the number of hybridization spots $(0,1,2$ and $>2)$ in 200 distinct, nonoverlapping, single or side-by-side, nuclei. Columnar nongoblet and goblet cells were separately assessed. Normal gastric and colon epithelia were used as controls for the IF expression of the gastric (MUC5AC and MUC6) and intestinal (MUC2) apomucins, respectively.

\section{Statistical analysis}

For statistical analysis $\chi^{2}$ and Fisher's exact test were used. A value of $P<0.05$ was considered as significant.

\section{Results}

\section{Phase I}

The study included 50 patients, 39 male and 11 female, with a mean age of 61.2 years (ranging from 24- to 83-years old). Barrett's esophagus length ranged from 3 to $10 \mathrm{~cm}$. Ten patients had two samples collected for short-term cell culture.

\section{Establishment and Phenotypic Characterization of Short-Term Cell Cultures}

A total of 60 biopsy samples were processed for short-term cell culture. Efficient growth of epithelial cells was obtained in 40 of the 60 (67\%) cases. In 20 cases, short-term cell culture was not achieved because of microbial contamination $(n=15)$ or insufficient growth $(n=5)$. The epithelial lineage of the cultured cells was confirmed by positive staining for the cytokeratins CAM 5.2 and AE1/AE3. The presence of a mixed, intestinal and gastric phenotype characteristic of Barrett's esophagus was confirmed by the expression of MUC2, MUC5AC and MUC6.

\section{Cytogenetic Analysis}

The results of cytogenetic analysis are summarized in Table 1.

Cytogenetics aberrations were observed in 27 of the $40(68 \%)$ successfully cultured cases. In 14 of them multiple abnormal clones were detected. Tetraploid (4n) cell populations were present in 10 of the $40(25 \%)$ cases. Structural chromosomal abnormalities were detected in 14 of the 40 cases (35\%) being duplications, and balanced translocations the most prevalent alterations. Chromosomes 1, 5, 9, 11, 14, 15 and 22 were involved in at least two cases. Breakpoint distribution analysis identified 1q21, $15 q 15$ and $15 q 22$ as recurrent breakpoints. Numerical chromosomal alterations were present in 16 of the $40(40 \%)$ cases. Loss of chromosome Y was detected in 14 out of 27 (52\%) male cases with efficient cell growth; gains of chromosomes 7 and 18 were present in six and two cases, respectively.

\section{Phase II}

\section{Combined IF-FISH study}

The results of the combined IF-FISH study are summarized in Tables 2, 3 and 4.

IF-FISH analysis for the phenotypic characterization of the elements carrying the abnormalities was performed in eight cases with chromosomal gains, six of chromosome 7 and two of chromosome 18. A total number of 4800 cells (4287 (89\%) columnar and 513 (11\%) goblet) was analyzed for the presence 
Table 1 Cases with cytogenetics abnormalities

Case Sex Age Karyotype

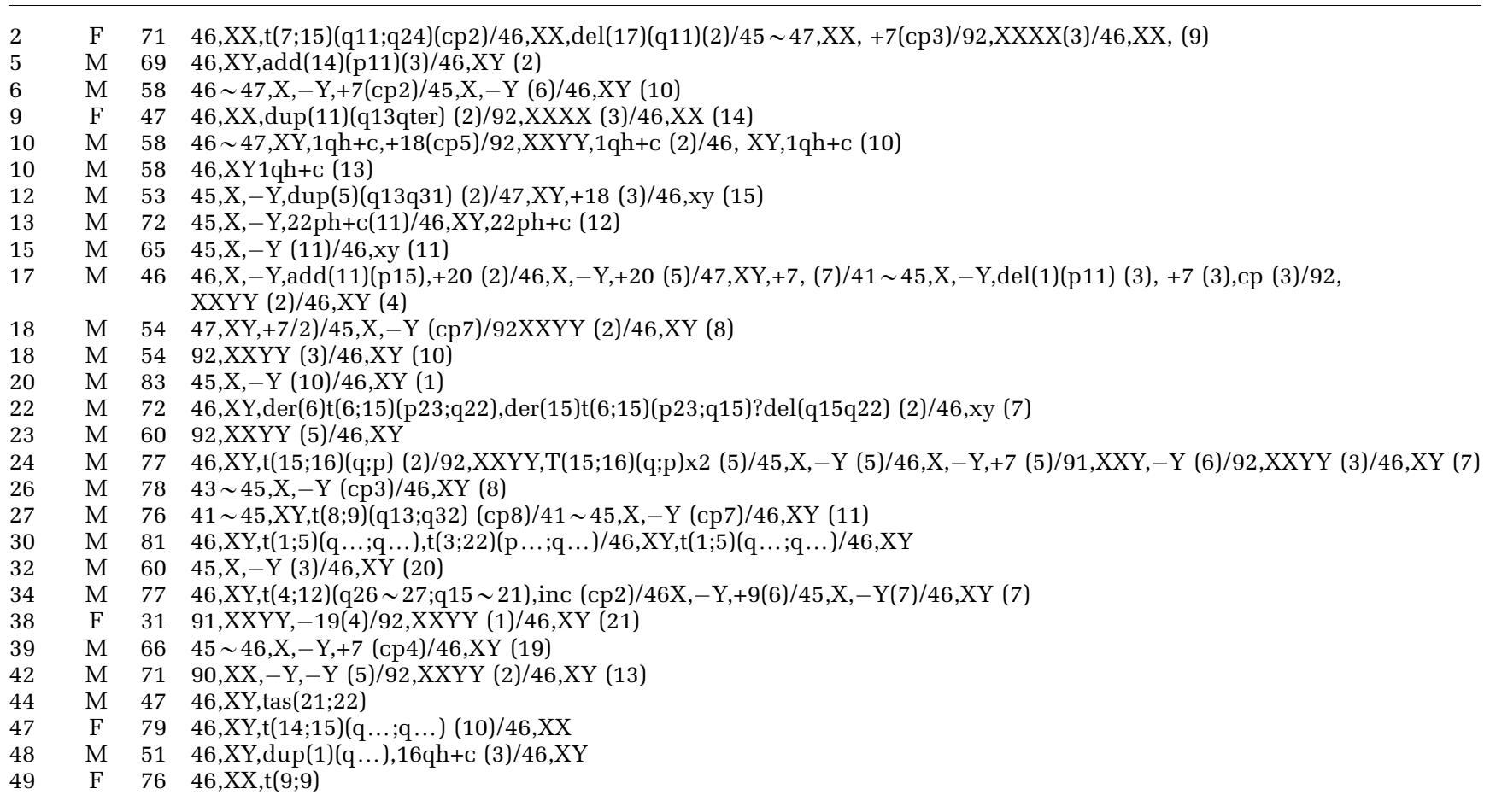

M, male; F, female.

Table 2 Number of cells analyzed in combined IF-FISH study

\begin{tabular}{lcc}
\hline Cells analyzed & Chromosome 7 & Chromosome 18 \\
\hline Total & $\mathbf{3 6 0 0}$ & $\mathbf{1 2 0 0}$ \\
Columnar cells & $3188(89 \%)$ & $1099(92 \%)$ \\
Goblet cells & $412(11 \%)$ & $101(8 \%)$ \\
No. of cells with gains & $\mathbf{3 1 8}(\mathbf{9} \%)$ & $\mathbf{8 9}(\mathbf{4} \%)$ \\
Columnar cells & $315(99 \%)$ & $87(98 \%)$ \\
Goblet cells & $3(1 \%)$ & $2(2 \%)$ \\
\hline
\end{tabular}

Total - number of cells analyzed for chromosomes 7 and 18.

Columnar cells - number (\%) of columnar cells analyzed for chromosomes 7 and 18.

Goblet cells - number (\%) of goblet cells analyzed for chromosomes 7 and 18.

No. of cells with gains - number of cells with gains of chromosomes 7 and 18.

Columnar cells - number (\%) of columnar cells with gains of chromosomes 7 and 18.

Goblet cells - number (\%) of goblet cells with gains of chromosomes 7 and 18.

of numerical alterations, on chromosomes 7 (3600) and 18 (1200).

Gain of chromosome 7 was detected in 318/3600 (9\%) cells (315 (99\%) columnar and $3(1 \%)$ goblet). Gain of 7 was more frequent in columnar than in goblet elements $(315 / 3188(10 \%)$ vs $3 / 412(1 \%)$ $P<0.05)$. For the evaluation of the phenotypic characteristics of the cells in the six cases with gain of chromosome 7, we analyzed 1200 (200 per case) cells per IF-FISH assay (Table 3). In IF-FISH assay for MUC2, 1064 columnar and 136 goblet cells were evaluated. MUC2 was detected in 207/1064 (19\%) columnar and in 91/136 (67\%) goblet elements. In columnar cells, gain of chromosome 7 was more frequent in elements without MUC2 (87/857 (10\%) vs $4 / 207(2 \%) P<0.05)$. There was no difference between the frequency of chromosome 7 gain in goblet elements with and without MUC2 (2/45 (4\%) vs 0/91). The IF-FISH assay for MUC5AC evaluated 1078 columnar and 122 goblet cells. MUC5AC was observed in 755/1078 (70\%) columnar and in 73/122 $(60 \%)$ goblet elements. There was no difference between the frequency of chromosome 7 gain in columnar cells with (Figure 1) and without MUC5AC (90/755 (12\%) vs 42/323 (13\%)). Gain of chromosome 7 was not observed in goblet cells (0/122) in IF-FISH assay for MUC5AC. IF-FISH assay for MUC6 analyzed 1046 columnar and 154 goblet cellular elements. MUC6 was detected in 429/1046 $(41 \%)$ columnar and in 60/154 (39\%) goblet cells. In columnar cells, gain of chromosome 7 was more frequent in elements without MUC6 (69/617 (11\%) vs $23 / 429(5 \%) P<0.05)$. There was no difference between the frequency of chromosome 7 gain in goblet elements with and without MUC6 (1/60 (2\%) vs $0 / 94$ ).

Gain of chromosome 18 was detected in 89/1200 $(7 \%)$ cells $(87(98 \%)$ columnar and $2(2 \%)$ goblet). Gain of 18 was more frequent in columnar than in goblet elements $(87 / 1099$ (8\%) vs $2 / 101$ (2\%) 
Table 3 Phenotypic characteristics of cells and chromosome 7 status

\begin{tabular}{|c|c|c|c|c|c|c|c|c|c|c|c|c|}
\hline \multirow[t]{3}{*}{ Chromosome 7} & \multicolumn{6}{|c|}{ Columnar } & \multicolumn{6}{|c|}{ Goblet } \\
\hline & \multicolumn{2}{|c|}{ MUC2 } & \multicolumn{2}{|c|}{$M U C 5 A C$} & \multicolumn{2}{|c|}{ MUC6 } & \multicolumn{2}{|c|}{ MUC2 } & \multicolumn{2}{|c|}{$M U C 5 A C$} & \multicolumn{2}{|c|}{ MUC6 } \\
\hline & $+v e$ & $-v e$ & $+v e$ & $-v e$ & $+v e$ & $-v e$ & $+v e$ & $-v e$ & $+v e$ & $-v e$ & $+v e$ & $-v e$ \\
\hline $2 \mathrm{~N}$ & 203 & 770 & 665 & 281 & 406 & 548 & 91 & 43 & 73 & 49 & 59 & 94 \\
\hline \multirow{2}{*}{$>2 \mathrm{~N}$} & & 87 & 90 & 42 & 23 & 69 & 0 & 2 & 0 & 0 & 1 & 0 \\
\hline & \multicolumn{2}{|c|}{$P<0.005$} & \multicolumn{2}{|c|}{$\mathrm{NS}^{*}$} & \multicolumn{2}{|c|}{$P<0.005$} & \multicolumn{2}{|c|}{$\mathrm{NS}^{* *}$} & \multicolumn{2}{|c|}{ NS } & \multicolumn{2}{|c|}{$\mathrm{NS}^{* *}$} \\
\hline
\end{tabular}

NS, nonsignificant.

${ }^{*} P$ equal to $0.61 ; \chi^{2}$ test.

${ }^{*} P$ equal to 0.10 and 0.20 respectively; Fisher's exact test.

Table 4 Phenotypic characteristics of cells and chromosome 18 status

\begin{tabular}{|c|c|c|c|c|c|c|c|c|c|c|c|c|}
\hline \multirow[t]{3}{*}{ Chromosome 18} & \multicolumn{6}{|c|}{ Columnar } & \multicolumn{6}{|c|}{ Goblet } \\
\hline & \multicolumn{2}{|c|}{ MUC2 } & \multicolumn{2}{|c|}{$M U C 5 A C$} & \multicolumn{2}{|c|}{ MUC6 } & \multicolumn{2}{|c|}{ MUC2 } & \multicolumn{2}{|c|}{$M U C 5 A C$} & \multicolumn{2}{|c|}{ MUC6 } \\
\hline & $+v e$ & $-v e$ & $+v e$ & $-v e$ & $+v e$ & $-v e$ & $+v e$ & $-v e$ & $+v e$ & $-v e$ & $+v e$ & $-v e$ \\
\hline $2 \mathrm{~N}$ & 72 & 269 & 167 & 170 & 135 & 199 & 25 & 14 & 16 & 11 & 6 & 26 \\
\hline \multirow{2}{*}{$>2 \mathrm{~N}$} & 4 & 16 & 11 & 25 & 7 & 24 & 0 & 0 & 0 & 0 & 2 & 0 \\
\hline & \multicolumn{2}{|c|}{$\mathrm{NS}^{*}$} & \multicolumn{2}{|c|}{$P<0.05$} & \multicolumn{2}{|c|}{$\mathrm{NS}^{*}$} & \multicolumn{2}{|c|}{ NS } & \multicolumn{2}{|c|}{ NS } & \multicolumn{2}{|c|}{$\mathrm{NS}^{* *}$} \\
\hline
\end{tabular}

NS, nonsignificant.

${ }^{*} P$ equal to 0.9 and 0.051 , respectively; $\chi^{2}$ test.

${ }^{* *} P$ equal to 0.061 ; Fisher's exact test.

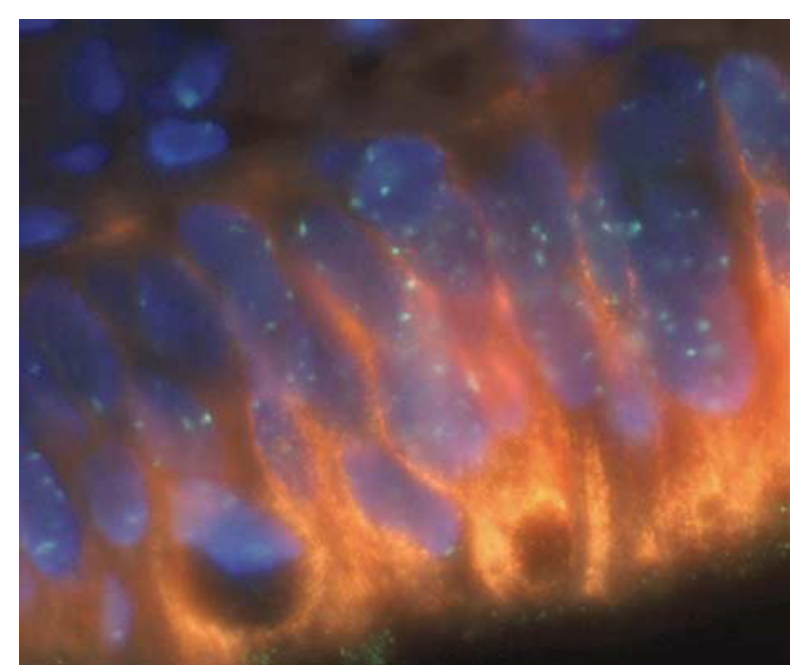

Figure 1 IF-FISH assay for chromosome 7 and MUC5AC. MUC5AC producing columnar cells (red/orange) with gain of chromosome 7 (green).

$P<0.05)$. For the phenotypic characterization of the cells with gain of chromosome 18 in the two cases detected, we analyzed 400 (200 per case) cells per IF-FISH assay (Table 4). In IF-FISH assay for MUC2, 361 columnar and 39 goblet cells were evaluated. MUC2 was detected in 76/361 (21\%) columnar and in $25 / 39(64 \%)$ goblet elements. No difference was observed between the frequency of chromosome 18 gains in columnar cells with and without MUC2 (4/ 76 (5\%) vs 16/285 (6\%)). In IF-FISH assay for MUC2, gain of chromosome 18 was not detected in goblet elements (0/39). The IF-FISH assay for MUC5AC evaluated 373 columnar and 27 goblet elements. MUC5AC was observed in 178/373 (48\%) columnar and in 16/27 (59\%) goblet elements. In columnar cells, chromosome 18 gain was more frequent in elements without MUC5AC (25/195 (13\%) vs 11/178 (6\%) $P<0.05)$. Gain of chromosome 18 was not detected in goblet cells $(0 / 27)$ by IF-FISH for MUC5AC. The IF-FISH assay for MUC6 evaluated 365 columnar and 35 goblet cells. MUC6 was expressed in 142/365 (39\%) columnar and in 9/35 $(26 \%)$ goblet elements. There were no differences between the frequency of chromosome 18 gain in columnar as well as in goblet cells with (Figure 2) and without MUC6 (7/142 (5\%) vs 24/223 (11\%)) and $(2 / 9(22 \%)$ vs $0 / 26)$.

\section{Discussion}

Chromosomal analysis of Barrett's esophagus cells confirmed that clonal, either numerical or structur- 


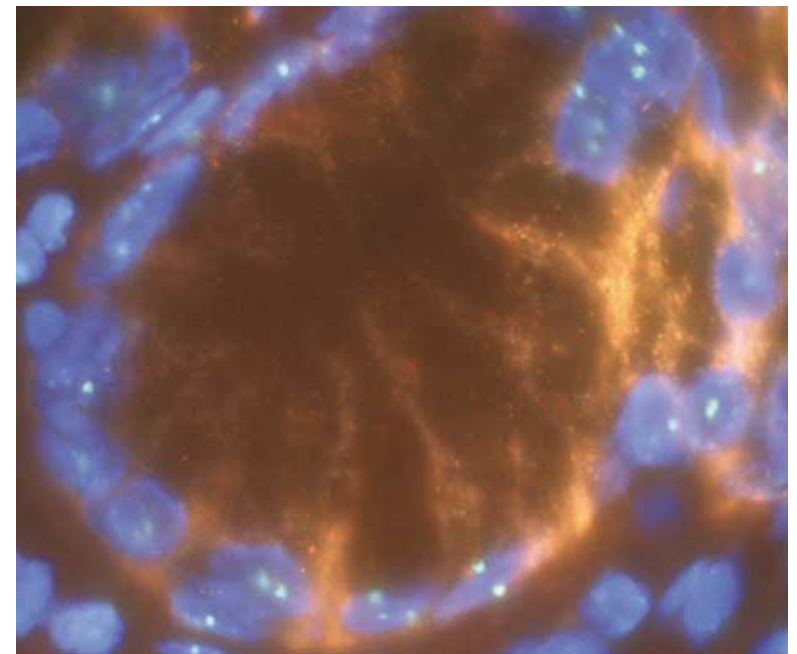

Figure 2 IF-FISH assay for chromosome 18 and MUC6. MUC6 producing goblet cells (red/orange) with gain of chromosome 18 (green).

al, abnormalities are frequent findings in nonneoplastic mucosa and demonstrated that the numerical alterations are present in both metaplastic cell lineage being independent of the cellular phenotype.

Barrett's esophagus is recognized as a phenotypically and genotypically heterogeneous structure formed by several distinct genetic clones. ${ }^{23-26}$ This study identified different clones with distinct karyotypes in the same patient confirming this statement and illustrating the chromosomal instability present in Barrett's esophagus even in the absence of dysplasia or cancer. This instability may facilitate the expansion of clones carrying particular abnormalities with selective advantages as has been described for loss of heterozigosity at $17 p$ and $9 p .{ }^{23-26}$

Conventional cytogenetics has, over other methods of chromosomal analysis, the ability to detect and characterize specific abnormalities. Its widespread routine application on Barrett's esophagus is not feasible mostly due to the difficulties in culturing nonneoplastic cells. Furthermore, the cellular heterogeneity of Barrett's esophagus limits the use of this technique because it does not allow the identification of the metaplastic population carrying the chromosomal changes. Therefore, immunophenotyping the cells resulting from successful Barrett's esophagus culture is an essential step to assure that we are selecting epithelial cells that maintain their native characteristics and not fibroblasts or epithelial-derived cells. All these difficulties may justify the small number of studies using this technique in Barrett's esophagus. ${ }^{17}$

In our study, the $66.6 \%$ success rate of short-term cell culture illustrates the difficulties in culturing nonneoplastic cells. The use of antibodies to cytokeratins CAM 5.2 and AE1/AE3 confirmed that the cultured cells were epithelial in origin and the positive staining for MUC5AC, MUC6 and MUC2 confirmed the presence of a mixed gastric and intestinal phenotype. This methodology, used in the 40 cases with efficient cellular growth, confirmed that the cultured cells analyzed in our study were representative of the metaplastic lineage usually present in Barrett's esophagus.

The abnormalities detected by conventional cytogenetic analysis are in accordance with the previous study of Garewal et al. ${ }^{17}$ As in their paper, structural and numerical abnormalities were found. We detected structural abnormalities in $35 \%$ of the cases. Their analysis enabled us to identify some recurrent breakpoints not described previously. These recurrent breakpoints may pinpoint to important genes involved in Barrett's tumorigenesis. 1q21 was one of these breakpoints. This locus has not been reported previously as rearranged in Barrett's esophagus or Barrett's adenocarcinoma. However, its involvement, curiously associated with activation of the MUC1 gene, has been demonstrated in lymphomas and malignant melanoma. ${ }^{27-29} \mathrm{~A}$ nonrandom involvement of chromosome 15 was also demonstrated in this study with breakpoints at $15 q 15$ and $15 q 22$. As far as we know, there is no description of genes linked to Barrett's adenocarcinoma in these particular regions. The chromosome breakpoint $15 q 15$ has been reported as involved in breast cancers. ${ }^{30} \mathrm{In}$ $15 q 22$ there are several genes that might play a role in proliferation, such as c-myc promoter-binding protein (IRLB), cytochrome $P 450$ polypeptide 1 and -2 (CYP1A1 and CYP1A2, respectively), mitogenactivated protein kinase 1 and -2 (MAP2K1 and MAP2K5, respectively) and carbonic anhydrase XII (CA12), whose involvement has been reported in acute leukemia. ${ }^{31}$ The nonrandom involvement of these breakpoints supports the need for further research targeting these particular chromosome locations in Barrett's tumorigenesis.

As in the study of Garewal et al, ${ }^{17}$ loss of chromosome $\mathrm{Y}$ was a frequent numerical abnormality and we also detected recurrent gains of chromosomes 7 and 18.

Loss of chromosome $\mathrm{Y}$ has been reported previously as being frequent in Barrett's esophagus with a prevalence ranging from 31 to $93 \% .{ }^{17,32,33}$ However, its relationship to malignancy remains uncertain. Previous in situ hybridization studies in Barrett's esophagus using centromeric probes demonstrated a correlation between chromosome $\mathrm{Y}$ loss and increasing severity of dysplasia. ${ }^{15,34,35}$ But, it remains to clarify its role as a cause or an effect. So far, no specific tumor suppressor genes have been mapped to the $\mathrm{Y}$ chromosome and Krishnadath et $a l,{ }^{36}$ who found no correlation between proliferation rates as detected by Ki-67 and loss of $\mathrm{Y}$ chromosome, did not confirm the hypothesis that its loss might confer proliferative advantage. Despite its unclear role as a side effect or a true initiating mechanism, all previous studies described chromo- 
some Y loss in Barrett's esophagus adjacent to neoplasia. As far as we know this is the first study demonstrating Y loss in 14/40 cases of Barrett's esophagus without associated dysplasia or carcinoma.

Gain of chromosome 7 has been reported previously in Barrett's esophagus by Garewal et al. ${ }^{17}$ The report from Walch et al, ${ }^{33}$ who performed comparative genomic hybridization in Barrett's cancer and adjacent premalignant mucosa supports that this might be an important genetic event during progression to malignancy. This overrepresentation of chromosome 7 might be responsible for the increased expression of EGFR, located at 7p11.15, described in Barrett's cancer and adjacent epithelium. ${ }^{37,38}$

Numerical abnormalities of chromosome 18 have been described in several neoplasia, namely of the gastrointestinal tract. ${ }^{39-41}$ In the work of Liu et $a l,{ }^{39}$ the gain or amplification of $18 \mathrm{p}$ in mucinous colorectal neoplasia was associated with aneuploidy and aggressive behavior. Stocks et $a l^{41}$ were able to separate junctional from distal gastric tumors based on a panel of genetic abnormalities, which includes numerical aberration of 18q. Nevertheless, as far as we know, the presence of chromosome 18 numerical changes on premalignant conditions such as Barrett's esophagus was not reported.

The meaning of gross chromosomal abnormalities in a nonneoplastic epithelium is presently unknown except for particular cytogenetic alterations associated with cancer risk. Their presence may be a ubiquitous event, such as the loss of $\mathrm{Y}$ chromosome, or may be indicative of a genetically abnormal epithelium. The cells presenting these changes may, or may not, progress to neoplasia, but they shall be one further step in the metaplasia $\rightarrow$ dysplasia $\rightarrow$ adenocarcinoma sequence as compared with cells harboring a normal karyotype.

Nevertheless, our main goal was, not to establish the presence of cytogenetic abnormalities in Barrett's esophagus, demonstrated previously, ${ }^{42-44}$ but to detect and to characterize the phenotype of the metaplastic cellular lineage carrying the abnormalities. For this purpose, we used numerical changes detected by cytogenetic analysis in an IF-FISH protocol. Because it is recognized that Y chromosome loss is age related and may be observed in normal tissues remaining an unspecific finding with unclear significance, we select the gains of chromosomes 7 and 18 to perform the IF-FISH analysis. Furthermore, the detection of chromosome loss by IF-FISH assay has technical pitfalls related to the section of three-dimensional structures that favor the use of chromosome gains in this assay. On the other hand, the selection of IF-FISH as a complementary technique for our cytogenetic analysis was based on its ability to recognize the distinct population involved.

In our IF-FISH study, gains of chromosomes 7 and 18 were more frequent in columnar than in goblet cells. Although goblet cells are considered a prerequisite to identify the premalignant condition, ${ }^{9,18}$ in our IF-FISH study the chromosomal gains were more frequent in the columnar population. This suggests that columnar nongoblet as well goblet cells of Barrett's esophagus, may harbor chromosomal abnormalities and may be prone to malignant transformation. The alterations being more frequent in the predominant cell lineage of Barrett's esophagus, the columnar nongoblet elements, this population also emerges a putative candidate to adenocarcinoma precursor.

On the other hand, we found that columnar and goblet cells with chromosomal gains may display gastric as well as intestinal phenotype. This confirms that Barrett's metaplastic elements may harbor abnormalities despite its cellular phenotype. In Barrett's esophagus, as in other metaplastic epithelia, the biological meaning of cells presenting chromosomal abnormalities and aberrant phenotype is still an unclear issue. As in other tumorigenic models related to chronic inflammation such as chronic atrophic gastritis ${ }^{45}$ and inflammatory bowel disease,${ }^{46-48}$ this may be related to the progressive development of simultaneous genotypically and phenotypically abnormal populations in the metaplasia $\rightarrow$ dysplasia $\rightarrow$ carcinoma sequence.

In conclusion, our study demonstrated that in Barrett's esophagus negative for dysplasia or cancer chromosomal instability is a frequent event, involves both metaplastic populations, columnar nongoblet and goblet cells, and is independent of the cellular phenotype. These challenge the consensus of considering goblet cells as the sole cell type involved in neoplastic progression in Barrett's esophagus.

\section{Acknowledgements}

This work was supported by a grant from Núcleo Regional do Sul/Liga Portuguesa Contra o CancroTerry Fox and a grant from Serviço de Saúde e Desenvolvimento Humano da Fundação Calouste Gulbenkian.

\section{References}

1 Spechler SJ, Goyal RK. Barrett's oesophagus. N Engl J Med 1986;315:362-371.

2 Spechler SJ, Goyal RK. The columnar-line oesophagus, intestinal metaplasia and Norman Barrett. Gastroenterology 1996;110:614-621.

3 Blot WJ, Devesa SS, Kneller RW, et al. Rising incidence of adenocarcinoma of the oesophagus and gastric cardia. JAMA 1991;265:1287-1289.

4 Devesa SS, Blot WJ, Fraumeni JF. Chaging patterns in the incidence of esophageal and gastric adenocarcinoma in the United States. Cancer 1998;83: 2049-2053. 
5 Cameron AJ. Epidemiology of columnar-lined oesophagus and adenocarcinoma. Gastroenterol Clin North Am 1997;26:487-494.

6 Paull A, Trier JS, Dalton MD, et al. The histologic spectrum of Barrett's esophagus. N Engl J Med 1976;295:476-480.

7 Chaves P, Cruz C, Suspiro A, et al. Gastric differentiation of Barrett's epithelium-an immunocytochemical study using MUC5AC and MUC6 antibodies. In: Pinotti HW, Cecconello I, Felix VN, Oliveira MA (eds). Recent Advances in Diseases of the Oesophagus. Proceedings of ESOPHAGUS 2001-VIII World Congress; 5-8 September 2001; S Paulo, Brazil. Monduzzi Editore International Proceedings Division: Bologna, 2001.

8 Chaves P, Cruz C, Pereira AD, et al. Gastric and intestinal differentiation in Barrett's metaplasia and associated adenocarcinoma. Dis Esophagus 2005;18: 383-387.

9 Weinstein WM, Ippoliti AF. The diagnosis of Barrett's oesophagus: goblets, goblets, goblets. Gastrointest Endosc 1996;44:91-95.

10 Haggitt RC. Barrett's oesophagus, dysplasia and adenocarcinoma. Hum Pathol 1994;25:982-993.

11 Offner FA, Lewin KJ, Weinstein WM. Metaplastic columnar cells in Barrett's esophagus: a common and neglected cell type. Hum Pathol 1996;27:885-889.

12 Ho SB, Shekels LL, Toribara NW, et al. Mucin gene expression in normal, preneoplastic, and neoplastic human gastric epithelium. Cancer Res 1995;55:26812690.

13 Reis CA, David L, Nielson PA, et al. Immunohistochemical study of MUC5AC expression in human gastric carcinomas using a novel monoclonal antibody. Int J Cancer 1997;74:112-121.

14 Barrett MT, Sanchez CA, Prevo LJ, et al. Evolution of neoplastic cell lineage in Barrett's oesophagus. Nat Genet 1999;22:106-109.

15 Beuzen F, Dubois S, Fléjou JF. Chromosomal numerical aberrations are frequent in oesophageal and gastric adenocarcinomas: a study using in-situ hybridization. Histopathology 2000;37:241-249.

16 Galipeau PC, Cowan DS, Sanchez CA, et al. 17p (p53) allelic losses, 4N (G2/tetraploid) populations and progression to aneuploidy in Barrett's oesophagus. Proc Natl Acad Sci USA 1996;93:7081-7084.

17 Garewal HS, Sampliner R, Liu Y, et al. Chromosomal rearrangements in Barrett's oesophagus. A premalignant lesion of esophageal adenocarcinoma. Cancer Genet Cytogenet 1989;15:281-286.

18 Sampliner RE. Practice guidelines on the diagnosis, surveillance, and therapy of Barrett's oesophagus. Am J Gastroenterol 1998;93:1028-1032.

19 Levine DS. Management of dysplasia in the columnarlined oesophagus. Gastroenterol Clin North Am 1997;26:613-634.

20 Khan MK, Pillar SP, Paradimos D, et al. Barrett's oesophagus: a technique for the culture of Barrett's esophageal cells. J Gastroenterol Hepatol 1997;12: 606-611.

21 Pandis N, Heim S, Bardi G, et al. Improved technique for short-term culture and cytogenetic analysis of human breast cancer. Genes Chromosomes Cancer 1992;5:14-20.

22 Mitelman F (ed). ISCN 1995: An International System for Human Cytogenetic Nomenclature. Krager: Basel, 1995.
23 Galipeau PC, Prevo LJ, Sanchez CA, et al. Clonal expansion and loss of heterozigosity at chromosomes $9 \mathrm{p}$ and $17 \mathrm{p}$ in premalignant esophageal (Barrett's) tissue. J Natl Cancer Inst 1999;91:2087-2095.

24 Prevo LJ, Sanchez CA, Galipeau PC, et al. p53-mutant clones and field effects in Barrett's oesophagus. Cancer Res 1999;59:4784-4787.

25 Wong DJ, Paulson TG, Prevo LJ, et al. $p 16^{I N K 4 a}$ lesions are common, early abnormalities that undergo clonal expansion in Barrett's metaplastic epithelium. Cancer Res 2001;61:8284-8289.

26 Suspiro A, Dias Pereira A, Afonso A, et al. Losses of heterozygosity on chromosomes $9 p$ and $17 p$ are frequent events in Barrett's metaplasia not associated with dysplasia or adenocarcinoma. Am J Gastroenterol 2003;98:728-734.

27 Dyomin VG, Palanisamy N, Lloyd KO, et al. MUC1 is activated in a B-cell lymphoma by the $\mathrm{t}(1 ; 14)(\mathrm{q} 21 ; \mathrm{q} 32)$ translocation and is rearranged and amplified in B-cell lymphoma subsets. Blood 2000;95:2666-2671.

28 Gilles F, Goy A, Remache Y, et al. MUC1 deregulation as the consequence of a $t(1 ; 14)(q 21 ; q 32)$ translocation in an extranodal lymphoma. Blood 2000;95: 2930-2936.

29 Smedley D, Sidhar S, Birdsall S, et al. Characterization of chromosome 1 abnormalities in malignant melanomas. Genes Chromosome Cancer 2000;28:121-125.

30 Sherif ZA, Danielsen M. Balanced t(11;15)(q23;q15) in a TP53(+/+) breast cancer patient from a Li-Fraumeni syndrome family. Cancer Genet Cytogenet 2006;168: 50-58.

31 Geurts van Kessel A, de Leeuw H, Dekker EJ, et al. Localization of the cellular retinoic acid binding protein (CRABP) gene relative to the acute promyelocytic leukemia-associated breakpoint on human chromosome 15. Hum Genet 1991;87:201-204.

32 Menke-Pluymers MB, van Drunen E, Vissers KJ, et al. Cytogenetic analysis of Barrett's mucosa and adenocarcinoma of the distal oesophagus and cardia. Cancer Genet Cytogenet 1996;90:109-117.

33 Walch AK, Zitzelsberger HF, Bruch J, et al. Chromosomal imbalances in Barrett's adenocarcinoma and the metaplasia-dysplasia-carcinoma sequence. Am J Pathol 2000;156:555-566.

34 Hunter S, Gramlich T, Abbott K, et al. Y chromosome loss in esophageal carcinoma: an in situ hybridisation study. Genes Chromosomes Cancer 1993;8:172-177.

35 Persons DL, Croughan WS, Borelli KA, et al. Interphase cytogenetics of esophageal adenocarcinoma and precursor lesions. Cancer Genet Cytogenet 1998;106: 11-17.

36 Krishnadath KK, Tilanus HW, Alers JC, et al. Detection of genetic changes in Barrett's adenocarcinoma and Barrett's oesophagus by DNA in situ hybridisation and immunohistochemistry. Cytometry 1994;15: 176-184.

37 Al-Kasspooles M, Moore JH, Orringer MB, et al. Amplification and over-expression of the EGFR and erbB-2 genes in human esophageal adenocarcinomas. Int J Cancer 1993;54:213-219.

38 Jankowski J, Hopwood D, Pringle R, et al. Increased expression of epidermal growth factor receptors in Barrett's oesophagus associated with alkaline reflux: a putative model for carcinogenesis. Am J Gastroenterology 1993;88:402-408.

39 Liu XP, Stato T, Oga A, et al. Two types of mucinous colorectal carcinoma characterized by laser scanning 
cytometry and comparative genomic hybridization. Int J Oncol 2004;25:615-621.

40 Skacel M, Paris PL, Pettay JD, et al. Diffuse large B-cell lymphoma of the stomach: assessment of microsatellite instability, allelic imbalance, and trisomy of chromosomes 3, 12 and 18. Diag Mol Pathol 2002;11:75-82.

41 Stocks SC, Pratt N, Sapes M, et al. Chromosomal imbalances in gastric and esophageal adenocarcinoma: specific comparative genomic hybridization-detected abnormalities segregate with junctional adenocarcinomas. Genes Chromosomes Cancer 2001;32:50-58.

42 Garewal HS, Leibovitz A, Sampliner RE, et al. Tissue culture of epithelial cells from esophageal specialized columnar epithelium (Barrett's oesophagus). Dig Dis Sci 1992;37:532-536.

43 Krishnadath KK, Tilanus HW, van Blankenstein M, et al. Accumulation of genetic abnormalities during neoplastic progression in Barrett's oesophagus. Cancer Res 1995;55:1971-1976.
44 Raskind WH, Norwood T, Levine DS, et al. Persistent clonal areas and clonal expansion in Barrett's Oesophagus. Cancer Res 1992;52:2946-2950.

45 Reis CA, David L, Correa P, et al. Intestinal metaplasia of human stomach displays distinct patterns of mucin (MUC1, MUC2, MUC5AC, and MUC6) expression. Cancer Res 1999;59:1003-1007.

46 Buisine MP, Desreumaux P, Leteurtre E, et al. Mucin gene expression in intestinal epithelial cells in Crohn's disease. Gut 2001;49:544-551.

47 Kushima R, Borchard F, Hattori T. A new aspect of gastric metaplasia in Crohn's disease: bidirectional (foveolar and pyloric) differentiation in so-called 'pyloric metaplasia' in the ileum. Pathol Int 1997;47:416-419.

48 Tatsumi N, Kushima R, Vieth M, et al. Cytokeratin 7/20 and mucin core protein expression in ulcerative colitisassociated colorectal neoplasms. Virchows Arch 2006;448:756-762. 